\title{
Sabbath Law and Mishnah Shabbat in Origen De Principiis
}

\section{Citation}

Cohen, Shaye J. D. 2010. Sabbath Law and Mishnah Shabbat in Origen De Principiis. Jewish Studies Quarterly 17 (2): 160-89.

\section{Published Version}

http://www.jstor.org/stable/40753511

\section{Permanent link}

http://nrs.harvard.edu/urn-3:HUL.InstRepos:33077878

\section{Terms of Use}

This article was downloaded from Harvard University's DASH repository, and is made available under the terms and conditions applicable to Open Access Policy Articles, as set forth at http:// nrs.harvard.edu/urn-3:HUL.InstRepos:dash.current.terms-of-use\#OAP

\section{Share Your Story}

The Harvard community has made this article openly available.

Please share how this access benefits you. Submit a story.

\section{Accessibility}




\section{Sabbath Law and Mishnah Shabbat in Origen De Principiis}

Origen (184/5 - 253/4 CE), the great theologian, scholar, and exegete, was primarily associated with two cities in the course of his life: Alexandria in Egypt and Caesarea in Roman Palaestina. He was educated in the former and began his career there; he moved to the latter in the early 230s, having visited it for a time in 215/6 CE. ${ }^{1}$ Throughout his writings Origen had a sustained interest in Judaism, in particular the Jewish exegesis of the Hebrew Scriptures. Origen sought out Jews who could help him establish the text or explain difficult words and phrases. ${ }^{2}$ Of course, as a pious Christian, Origen believed that the Jews do not understand their own Scriptures. For him the truth of the Bible is revealed solely through faith in Christ; the Bible is a Christian book, and the Jews, because they deny Christ, misapprehend the very text that they claim to interpret. Nonetheless, Origen thought, the Jews are a source of useful information to an exegete of Scripture.

I would like to thank Bernard Septimus and Aharon Shemesh for their comments and suggestions. All translations are mine unless otherwise credited.

${ }^{1}$ For convenient summaries of Origen's life and career, see e.g. Henri Crouzel, “Origen and Origenism," New Catholic Encyclopedia 10.653-661 (Detroit: Gale, 2003; 2nd ed; Gale Virtual Reference Library accessed through Harvard University on 9 July 2008); Theologische Realenzyklopädie 25 (1995) s.v. Origenes; The Westminster Handbook to Origen, ed. John A. McGuckin (Louisville: Westminster John Knox Press, 2004) 1-23. All modern biographies of Origen are based on the biography of Origen in Eusebius, Historia Ecclesiastica book 6.

2 Jerome noted Origen's fondness of citing Jewish informants in support of his scriptural interpretations. See Contra Rufinum 1.13 (CCSL 79.12-13): Ipse Origenes et Eusebius et Clemens aliique conplures, quando de Scripturis aliqua disputant et volunt approbare quod dicunt, sic solent scribere, "Referebat mihi Hebraeus" et "audivi ab Hebraeo," et "Hebraeorum ista sententia est." On Origen and the Jews the standard modern study is the book of that title by Nicholas de Lange (Cambridge University Press, 1976). Other bibliography includes: H. Grätz, "Hillel, der Patriarchensohn," MGWJ 30 (1881) 433-443; W. Bacher, "The Church Father Origen and Rabbi Hoshaya," JQR o.s. 3 (1890) 357-360; Samuel Krauss, "The Jews in the Works of the Church Fathers," JQR o.s. 5 (1893) 122-157; A. von Harnack, Der kirchengeschichtliche Ertrag der exegetischen Arbeiten des Origenes 1. Teil Hexateuch und Richterbuch (TU 42,3 1918) 47-51; 2. Teil Die beiden Testamente mit Ausschluss des Hexateuchs und des Richterbuchs (TU 42,4 1919) 81-87; A. Marmorstein, "Deux renseignements d'Origène concernant les juifs," REJ 71 (1920) 190-199; Gustave Bardy, "Les traditions juives dans l'oeuvre d'Origène," RB 34 (1925) 217-252; Y. Baer, "Israel, the Christian Church, and the Roman Empire," Scripta Hierosolymitana 7 (1961) Studies in History, ed. A. Fuks and I. Halpern, 79-149, esp. 98-118; Ephraim E. Urbach, "The Homiletical Interpretations of the Sages and the Expositions of Origen on Canticles, and the Jewish-Christian Disputation," Scripta Hierosolymitana 22 (1971) Studies in Aggadah, ed. J. Heinemann and Dov Noy, 247-275; Hans Bietenhard, Caesarea, Origenes, und die Juden (Stuttgart: W. Kohlhammer, 1974; Franz Delitzsch Vorlesungen 1972); Heinz Schreckenberg, Die christlichen Adversus Judaeos Texte ... 1.-11.Jh. (Peter Lang 1982) 228-235; Reuven Kimelman, "Rabbi Yohanan and Origen on the Song of Songs," HTR 73 (1980) 567-595; Marc Hirshman, A Rivalry of Genius (SUNY Press, 1996) 67-94; J. A. McGuckin, "Origen on the Jews," Studies in Church History 29: Christianity and Judaism (Cambridge, MA: Ecclesiastical History Society, 1992) 1-13; Elizabeth Clark, "Origen, the Jews, and the Song of Songs: Allegory and Polemic in Christian Antiquity," in Perspectives on the Song of Songs (2005) 274-293. 
This essay is devoted to a passage from the De Principiis in which Origen cites and rejects - the Jewish interpretation of two Scriptural verses. ${ }^{3}$ The De Principiis (in Greek Peri Arkhôn), "On the Principles," completed in Alexandria in the early 220s, is a systematic exposition of the Christian faith. In four books Origen sets out the Christian beliefs about God, creation, free will, and Scripture. In the fourth and fifth centuries a fierce debate arose about Origen's "orthodoxy," and the De Principiis was one of the books that stood at the center of the controversy. Defenders and detractors came to the fore, and there was much discussion as to exactly what Origen said and exactly what Origen meant. As a result of these debates, the Greek original of the De Principiis ultimately disappeared. About one sixth of the De Principiis is extant in Greek, thanks to the Philocalia, "the Love of Beauty," an anthology of excerpts from the writings of Origen (and others) that was assembled by admirers of Origen in the fourth century. Our knowledge of the rest of the De Principiis derives almost entirely from the Latin translation of Rufinus (ca. 345-411), another admirer of Origen, completed around the year 398. Unfortunately, in order to defend the De Principiis, Rufinus translated it rather loosely, omitting problematic statements, adding words of explanation, rearranging the material, etc. The translation is actually a paraphrase, faithful to the gist of the original but unreliable as a mirror of what Origen actually wrote. ${ }^{4}$ Fortunately for us, the passage that is at the heart of this article is extant in Greek via the Philocalia, and we may safely assume that this Greek text brings us much closer to what Origen wrote than does the Latin of Rufinus. As we shall see, even in our passage, in which no great doctrine of the Christian faith hangs in the balance, Rufinus' version differs in several details from the Greek of the Philocalia.

\section{Origen De Principiis 4.3.2}

The subject of book 4 of the De Principiis is Scripture, its inspiration by God and its interpretation by mortals. In De Principiis 4.3.2 Origen argues that the "literal" interpretation of the laws of scripture cannot be the "real" or correct interpretation,

\footnotetext{
${ }^{3}$ In spite of its importance and interest this passage has not attracted much scholarly attention. Of the studies listed in note 2, only de Lange, Origen 40 and 92-93 discusses the passage at any length; alas, de Lange's discussion is marred by some serious errors; see notes 25 and 62 below. Lorenzo Perrone, "L'argomentazione di Origene nel trattato di ermeneutica biblica: Note di lettura su Peri Archon IV 1-3," Studi Classici e Orientali 40 (1990) 161-203 does not discuss our passage.

4 The standard modern edition of the De Principiis, including the Greek of the Philocalia, the Latin of Rufinus, and scattered fragments, is by Paul Koetschau in Die griechischen christlichen Schriftsteller 22 (1913; Origenes Werke 5) which serves as the basis for Herwig Görgemanns and Heinrich Karpp, Origenes Vier Bücher von den Prinzipien (Darmstadt: Wissenschaftliche Buchgesellschaft, 1985; with German translation) and H. Crouzel and M. Simonetti, Origène Traité des Principes (Paris: 1978-1984; Sources chrétiennes 252, 253, 268, 269, 312; with French translation). English translations of the De Principiis: Frederick Crombie in the Ante Nicene Fathers (vol. 4; original edition Edinburgh, 1869; original American edition 1888; frequently reprinted), available online at http://www.ccel.org/ccel/schaff/anf04.vi.v.html and various other sites; G. W. Butterworth, Origen On First Principles (London: SPCK, 1936; repr. New York: Harper Torchbooks, 1966). On the quality of Rufinus' translation see e.g. Koetschau's introduction cxxviii-cxxxvii; Butterworth's preface xlvi-lii. The date of the De Principiis derives from Eusebius HE 6.24.3; Koetschau puts the date at not long after 220 (introduction ix-xv), but the exact date is not known.
} 
because the literal interpretation has Scripture make demands that are either nonsense (alogon) or impossible to observe (adunaton). ${ }^{5}$ To support this argument Origen adduces six scriptural examples.

Origen gives two examples of laws that are nonsense if understood literally. First, Leviticus 11:14 lists, among the birds that may not be eaten, the vulture (үũ gyps, the LXX's translation of דאה $\left.d a^{\prime} a h\right)$. This law makes no sense, says Origen, since no one, no matter how hungry, would ever eat a vulture. Second, Genesis 17:14 orders the destruction of babies who are left uncircumcised after the eighth day of life. This law too makes no sense, says Origen, since not the babies but the parents should be liable to the penalty for violating the law. These laws, if read literally, are nonsense (alogon), proof that the laws of Scripture must be interpreted non-literally.

Origen gives four examples of laws that are impossible to observe if understood literally. First, Deuteronomy 14:5 lists, among the animals that may be eaten, the goat-

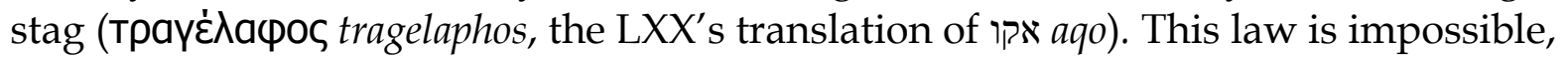
says Origen, since the goat-stag is a creature that does not exist. ${ }^{6}$ Second, Deuteronomy 14:12 (and Leviticus 11:13) lists, among the birds that may not be eaten, the griffin (Ypú $\Psi$ gryps, the LXX's translation of פרס peres). This law too is impossible, says Origen, since no human has ever caught a griffin. Third, Exodus 16:29 demands that every Israelite shall "sit" in his dwelling for the duration of the Sabbath; this law too is impossible if understood literally, says Origen, since no one can sit for a whole day and not move from his seat. Fourth and last, Jeremiah 17:21 prohibits carrying a burden on the Sabbath day; this law too is impossible if understood literally, says Origen (he does not explain why). These laws, if read literally, are impossible (adunaton) to be observed, proof that the laws of Scripture must be interpreted non-literally.

I am not concerned here with the quality of these arguments, or with the history of Christian exegesis of the laws of the Torah. Nor am I concerned here with the arguments from tragelaphos and griffin, from the inedible birds and the non-circumcised baby. I am concerned rather with the details of the laws of the Sabbath that Origen provides in his analysis of Exodus 16:29 and Jeremiah 17:21. Here is the text of the

\footnotetext{
${ }^{5}$ Cf. Homilia in Leviticum 4.7 (GCS Origenes Werke 6 p. 327): Iudaeorum vero doctores et impossibilia haec et irrationabilia, sequentes litteram, faciunt.

${ }^{6}$ For Origen, as for Aristotle, the tragelaphos is the parade example of a mythical creature that does not exist; see Steier, "Tragelaphos," PWRE 6A,2,1894-1895, summarized in Der neue Pauly 12/1,734.

Diodorus of Sicily 2.51.2, however, believes that the tragelaphos (and other such animal hybrids) is real. The rabbinic equivalent to the tragelaphos is the koy see Tosefta Bikkurim 2.1-2 (p. 289 ed. Lieberman) and Tosefta Kilayim 5.4 (p. 222 ed. Lieberman). Like Diodorus of Sicily, the rabbis assume that the tragelaphos/koy is real. Rabbinic musings on the tragelaphos/koy provide a window into the workings of rabbinic taxonomy; see the brilliant article by Judith Romney Wegner, "Tragelaphos Revisited: the Anomaly of Woman in the Mishnah," Judaism 37,2 (Spring 1988) 160-172, esp. 160-163. (Wegner refers to the koy as a mythical beast, but there is no indication that the rabbis thought of it as mythical.)
} 
relevant part of the passage, first of the Philocalia, then of Rufinus; for ease of reference I have divided the passage into five units marked (A) through (E): ${ }^{7}$

From De Principiis 4.3.2, as preserved by the Philocalia:

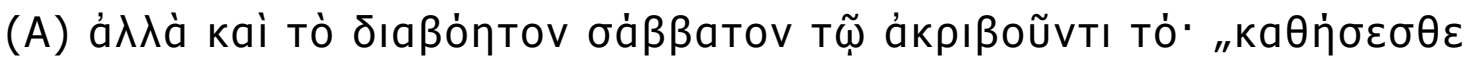

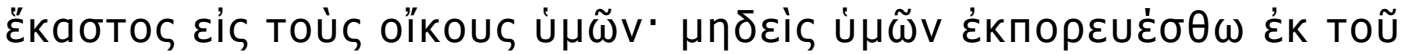

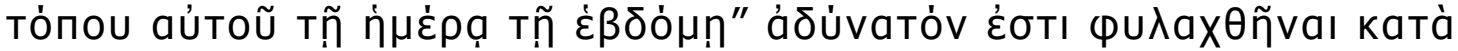

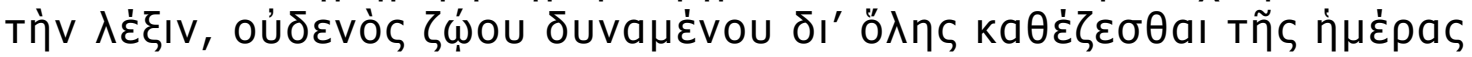

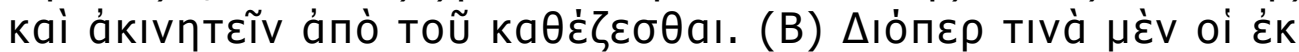

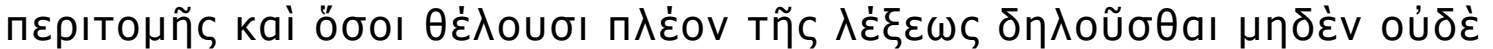

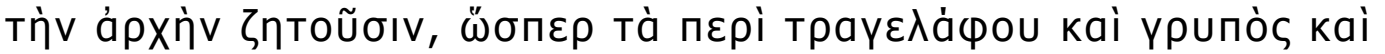

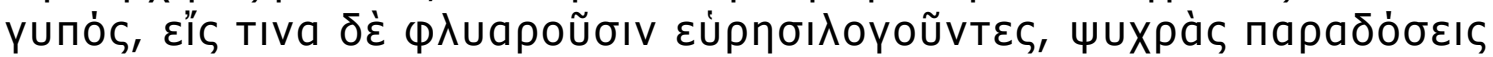

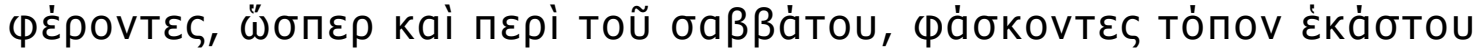

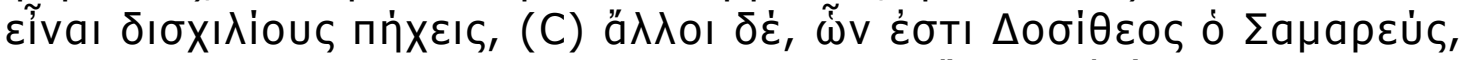

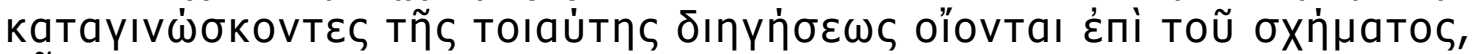

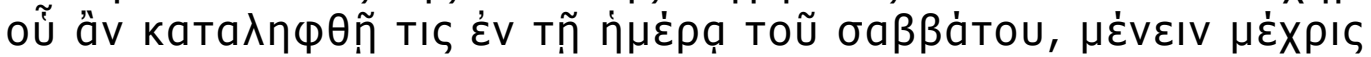

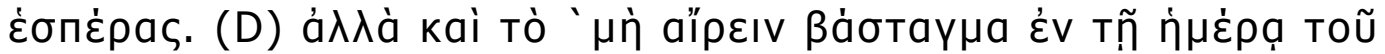

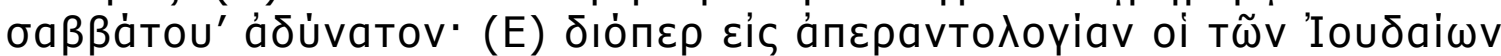

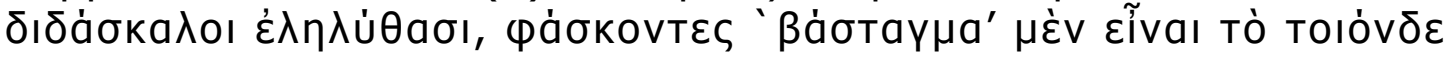

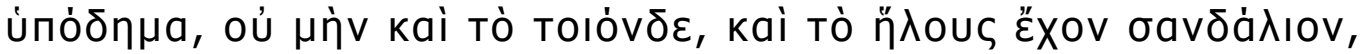

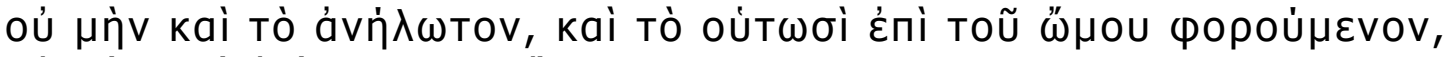

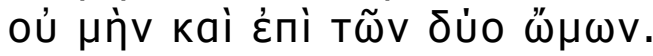

(A) Moreover, to the one who carefully reads the verse Each of you shall sit in your houses; let none of you go out from his place on the seventh day (Exodus 16:29), the celebrated Sabbath is impossible to be observed literally, since no living creature is able to sit for a whole day and not move from sitting. (B) Therefore, those of the circumcision, and all those who maintain that nothing more than the literal is signified (by Scripture), do not seek the explanation for some matters, such as the goat-stag, the griffin, and the vulture; while on other matters they talk nonsense, arguing perversely, bringing forward cold traditions, as for instance when they say, in reference to the Sabbath, that each one's place is two thousand cubits. (C) Others, however, among whom is Dositheus the Samaritan, condemning such an interpretation, believe that in the position in which one was caught on the Sabbath day one is to remain until evening. (D) Further, the verse not to lift a burden on the Sabbath day (Jeremiah 17:21) is impossible. (E) Therefore the teachers of the Jews have come to endless argumentation, asserting that one kind of footwear is a burden but another is not, and that a sandal with nails is a burden but one without nails is not, and that what is carried just-so on one shoulder is a burden but not what is carried on both.

\section{The passage as interpreted by Rufinus:}

7 Origen De Principiis 4.3.2 pp. 326-327 ed. Koetschau; pp. 736-739 ed. Görgemanns and Karpp; pp. 348353 ed. Crouzel and Simonetti (Sources chrétiennes 268). My translations are based on Butterworth's. 
(A) Sed et de sabbati opinatissima observatione ita dicit, "Sedebitis unusquisque in domibus vestris, nullus movebitur de loco suo in die sabbatorum." Quod utique inpossibile est observari secundum litteram; nullus enim hominum potest tota die ita sedere, ut non moveatur de eo loco, in quo sederit. (B) De quibus singulis hi quidem, qui ex circumcisione sunt, et quicumque in scripturis sancits nihil amplius intellegi volunt praeterquam indicatur ex littera, haec, ne requirenda quidem arbitrantur de tragelafo et grifo et vulture, fabulas autem quasdam inanes et frigidas commentantur, ex nescio quibus traditionibus proferentes de sabbato, dicentes unicuique locum suum reputari intra duo milia ulnas. (C) Alii vero, ex quibus est Dositheus Samaritanus, notant quidem huiuscemodi expositiones, ipsi autem ridiculosius aliquid statuunt, quia unusquisque quo habitu, quo loco, qua positione in die sabbati fuerit inventus, ita usque ad vesperam debeat permanere, id est vel si sedens, ut sedeat tota die, vel si iacens, ut tota die iaceat. (D) Sed et quod ait 'non levare onus in die sabbati' inpossibile mihi videtur. (E) Ex his enim ad fabulas infinitas, sicut sanctus apostolus dicit, Iudaeorum doctores devoluti sunt, dicentes non reputari 'onus,' si calciamenta quis habeat sine clavis, 'onus' vero esse, si galliculas quis cum clavis habuerit; et si quidem supra unum umerum aliquid portaverit quis, 'onus' iudicant, si vero supra utrumque, negabunt esse 'onus.'

(A) Moreover, regarding the celebrated observance of the Sabbath, he (Moses) speaks thus, You shall sit, each of you, in your houses; no one shall move from his place on the day of the Sabbath (Exodus 16:29). This, however, is impossible to be observed literally; for no person can sit for a whole day so as never to move from the place where he is sitting. (B) Regarding these individual points, those who are of the circumcision, and all those who maintain that in the sacred scriptures nothing more is to be understood than what is indicated by the letter, think that the matters concerning the goat-stag, the griffin, and the vulture, need not be investigated; concerning the Sabbath, however, they invent foolish and cold fables, drawing from some traditions or another, saying that each one's place is to be reckoned as up to two thousand cubits. (C) Others, however, among whom is Dositheus the Samaritan, condemn interpretations of this kind and yet themselves posit something still more ridiculous, namely, that in whatever posture or place or position a person is found on the Sabbath day he should remain thus until evening; that is, if sitting he should sit all day; if lying down, he should lie down all day. (D) But, as to what it says not to lift a burden on the Sabbath day (Jeremiah 17:21), this appears to me to be impossible. (E) For from these words the teachers of the Jews fall into endless fables, as the holy apostle says (1 Timothy 1:4), saying that it is not reckoned a burden if one has shoes (calciamenta) without nails, but that it is a burden if one has shoes (galliculas) with nails; and if one should carry something on one shoulder, they deem it a burden, but if one should carry it on both, they say it is not a burden. 
In this paragraph Origen treats five points: (A) the literal interpretation of Exodus 16:29; (B) the Jewish interpretation of Exodus 16:29; (C) Dositheus the Samaritan and others on Exodus 16:29; (D) the interpretation of Jeremiah 17:21; (E) the Jewish interpretation of Jeremiah 17:21. I shall treat each of these points in turn.

\section{(A) The literal interpretation of Exodus 16:29}

Moreover, to the one who carefully reads the verse Each of you shall sit in your houses; let none of you go out from his place on the seventh day (Exodus 16:29), the celebrated Sabbath is impossible to be observed literally, since no living creature is able to sit for a whole day and not move from sitting.

Origen regularly claims that the Jews read scripture "literally"; in one passage he even calls a literal reading Iudaicus sensus. ${ }^{8}$ The argument of De Principiis 4.3.2 is that many of the laws of Moses cannot be understood literally, hence Jewish exegesis must be wrong. "Literally" for Origen means "not informed by a belief in Christ." His "literal" is not necessarily what we call "literal," and is not necessarily what the medieval Jewish exegetes called peshat (the "plain" or "simple" meaning). ${ }^{9}$ Thus both Rashi (1040-1105) and Ibn Ezra (1089-1164) observe that according to its "plain" meaning Exodus 16:29 is an instruction from Moses to the Israelites in the desert: the Israelites may gather manna outside the camp six days a week, but on the Sabbath they are to remain in their place and not go out. In other words, in context the verse is an instruction to the Israelites of a specific time and place, not a command about Sabbath observance for all times and all places. ${ }^{10}$ Origen, no less than his Jewish interlocutors, however, neglected this plain meaning and through a decidedly non-contextual interpretation read the verse as if it were an eternal commandment of God about Sabbath observance.

When read literally, Origen says, Exodus 16:29 makes an impossible demand: to sit in one's place for the entire duration of the Sabbath. ${ }^{11}$ The crucial part of the verse

${ }^{8}$ De Principiis 2.11 .2 p. 186 ed. Koetschau. On Jewish literalism in Origen see e.g. Harnack, Der kirchengeschichtliche Ertrag....1. Teil Hexateuch 47-51; De Lange, Origen and the Jews 82-83; Peter Martens, "Why does Origen accuse the Jews of 'literalism'? A case study of Christian identity and biblical exegesis in antiquity," Adamantius 13 (2007) 218-230.

${ }^{9}$ For a recent discussion see Martin Lockshin, "Peshat and derash in Northern France," in his Rashbam's Commentary on Deuteronomy (Brown Judaic Studies 340; Providence RI, 2004) 1-25.

10 James Kugel, Traditions of the Bible (Harvard University Press, 1998) 648, “Theoretically, then, this commandment not to leave one's 'place' might well be understood to have applied only during the time of the wilderness wanderings, and to have been given specifically with regard to manna. However, this is not how ancient interpreters saw it; this law applied to them as well." Kugel writes "theoretically" because even though Rashi and Ibn Ezra realize that this is what the verse "really" means, they know full well that this is not how the verse is understood in rabbinic tradition.

11 The same argument appears in Origen's Commentary on Romans 1.12 (PG 14:856) : Per litteram namque infirmatur lex, ut non possit impleri. Quis enim impleret vel de sabbato quod scriptum est non te movebis de loco tuo in die sabbatorum - quomodo enim fieri poterat ut se aliquis penitus non moveret de loco suo? I cite the text from Der Römerbriefkommentar des Origenes: kritische Ausgabe der Übersetzung Rufins, ed. Caroline Hammond Bammel (Freiburg: Herder 1990-1997; 3 vols.) vol. 1 pp. 69-70. 
reads as follows: השביעי ביום ממקמו איש יצא אל תחתיו איש שבו ("sit each person where you are; let no one go out from his place on the seventh day") which contains two obscure expressions. What is meant by תחתיו? What is meant by ממקמו? The LXX interprets the former freely, translates the latter closely, and adds an obscurity of its own: кaӨウ் $\sigma \sigma \theta \varepsilon$

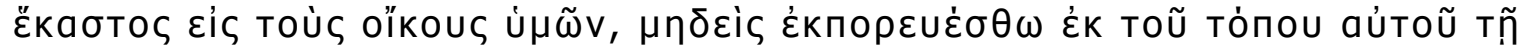

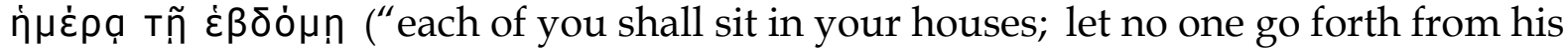
place on the seventh day"). The interpretation of תחתיו as "in your houses" is remarkable, but since Origen does not comment on it I do not need to either.12 ממקמו translated literally "from his place." What exactly this means is no clearer in the Greek than in the Hebrew. The obscurity added by the LXX is its literal translation of שבו. The Hebrew root ישב YSHB in the Bible can mean either "to dwell" or "to sit." When it has the former meaning the LXX usually translates it with oikizein "to dwell" or katoikizein "to dwell in"; when it has the latter meaning the LXX usually translates it with kathêsthai or kathizein, "to sit" or "to sit upon." Hence Origen, who is reading the Bible in Greek, wonders why Exodus 16:29 orders the Israelites to "sit" in their houses for the duration of the Sabbath; would it not have been more sensible of Scripture to command the Israelites to "dwell" in their houses? Rather than conclude that this locution is a good example of a Hebraism in Septuagintal Greek, Origen argues that it proves that Scripture intends to show the impossibility of a literal interpretation, "since no living creature is able to sit for a whole day and not move from sitting." 13

Contradicting Origen, other texts imply that literal observance of Exodus 16:29 was entirely possible; some Jews did, or at least were reputed to, "sit" or recline for the duration of the Sabbath day. ${ }^{14}$ Hippolytus writes of the Essenes that on the Sabbath "they do not move any utensil, nor do they defecate -- some do not even leave the couch."15 Jerome notes that "it is no profit to sit on the Sabbath, or to sleep, and to open the mouth wide at feasts" - Jerome seems to think that Jews spend the Sabbath sitting (and sleeping or eating). ${ }^{16}$ Origen himself in paragraph (C) cites Dositheus the

\footnotetext{
12 For discussion see Lutz Doering, Schabbat: Sabbathalacha und -praxis im Frühjudentum (TSAJ 78; MohrSiebeck, 1999) 91. There is a Hexaplaric variant par' heautôi; see the apparatus in the Göttingen Septuagint, as well as F. Field, Origenis Hexaplorum Quae Supersunt (Oxford: Clarendon Press, 1875) 1.110.

${ }^{13}$ Elsewhere too the LXX, in a fit of literalism, uses kathêsthai/ kathizein to translate ישב YSHB even when it would appear that the meaning is "dwell" rather than "sit." See e.g. LXX Genesis 19:30, 38:11, Exodus 24:18 (in v.l., where the MT has וישב rather thand and especially Leviticus 8:35. The standard lexica show that classical authors too occasionally use kathêsthai/ kathizein with the meaning "dwell, reside."

${ }^{14}$ Not to mention the prophet Ezekiel who lay on his side for 390 days (Ezekiel 4:4-9)!

${ }^{15}$ Hippolytus, Refutatio Omnium Haeresium 9.25.2, p. 370 ed. Marcovich. The clause "some do not even

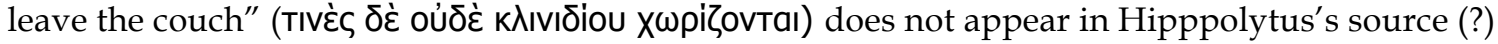
Josephus, BJ 2.147. For discussion see Christoph Burchard, “Die Essener bei Hippolyt," Journal for the Study of Judaism 8 (1977) 1-41, at 37-38.

${ }^{16}$ Jerome Commentary on Isaiah 56.2 (CCSL 73A.630): quod sit autem sabbatum quod praecipit observandum sequens versus ostendit: custodiens manus suas ne faciat omne malum. Neque enim prodest sedere in sabbato, sive dormire, et epulis inhiare. Sed si bona faciens quiescat in malis ... This passage is cited by both Burchard and Marcovich. Cf. too Commentary on Isaiah 53.12 (CCSL 73A:597): Ex quo qui dispensatoriam inter Petrum et Paulum contentionem uere dicunt iurgium fuisse atque certamen, ut
} 
Samaritan who, at least in the interpretation of Rufinus, advocates a literal observance of Exodus 16:29 (see below). In the tenth century Karaite exegetes polemicized against the Rabbinites, arguing that Exodus 16:29 prohibits any movement from one's place on the Sabbath. ${ }^{17}$

In any case, according to Origen, a literal reading of Exodus 16:29 is impossible. How, then, should the verse be interpreted? Metaphorically ("spiritually"), of course. In his commentary on Romans Origen writes that a Christian "will teach that Sabbaths are to be observed by not carrying around the burden of sin but by standing in one's place steadfastly." 18 In his Homilies on Numbers he writes: ${ }^{19}$

Therefore he who abstains from the works of the world and is free for spiritual activity, he it is who offers the sacrifice of the Sabbath and celebrates the Sabbath feast.

He carries no burden on the way. ${ }^{20}$ For the burden is every sin ...

On the Sabbath everyone sits in his place and does not leave it [Exodus 16:29]. What, then, is the spiritual place of the soul? Its place is righteousness, truth, wisdom, holiness and everything which Christ is, that is the place of the soul. The soul ought not to leave this place, if it is to keep the true Sabbath and celebrate with sacrifices the feast day of the Sabbath ...

On the Sabbath a Christian will not carry the burden of sin and will not leave the place of righteousness and truth, which is the place of Christ. Surely by "Sabbath" here

blasphemanti Porphyrio satisfaciant, et ueteris legis caeremonias in Ecclesia Christi a stirpe credentis Israel asserunt esse seruandas, debent et auream in mille annis exspectare Hierusalem, ut uictimas immolent et circumcidantur, ut in sabbato sedeant, dormiant, saturentur, inebrientur et surgant ludere, qui ludus offendit Deum.

17 Aron Freimann, "Meschullam b. Kalonymos' Polemik gegen die Karäer," Judaica: Festschrift zu Hermann Cohens Siebzigstem Geburtstage (Berlin: Cassirer, 1912) 569-578. It is not clear whether the Karaites of this period ( $10^{\text {th }}$ century) actually observed the Sabbath in this manner, or whether they simply were trying to score points against the Rabbinites. Certainly Karaites of later centuries moved about on the Sabbath, no less than the Rabbinites. See Judah Rosenthal, "Al hishtalshelut halakhah besefer berit damesek," [On the Development of Law in the Damascus Covenant] in Sefer ha Yovel mugash likhevod R. Dr. Shimeon Federbusch, ed. Y.L. HaKohen Maimon (Jerusalem: Mosad haRav Kook, 1961/5721) 292-303, at 302-303.

18 Commentary on Romans 5.1 (vol. 2 p. 390 ed. Hammond Bammel = PG 14.1020): sed et sabbata observari docebit non portando onera peccati sed stando unumquemque stabiliter in loco suo.

${ }^{19}$ Homilies on Numbers 23.4.2, edited by Louis Doutreleau, Origène Homélies sur les Nombres III (Sources chrétiennes 461) 122-124: Qui ergo cessavit ab operibus saeculi et spiritalibus actibus vacat, iste est qui sacrificium Sabbati et diem festum agit Sabbatorum. Neque onera portat in via: onus enim est omne peccatum ... In Sabbato unusquisque sedet in loco suo et non procedit ex eo: Quis ergo est locus animae spiritalis? Iustitia locus eius est, veritas, sapientia, sanctificatio et omnia quae Christus est, locus animae est. Ex quo loco eam non oportet exire, ut vera Sabbata custodiat et diem festum in sacrificiis exigat Sabbatorum. My translation is based on R. J. Bauckham, "Sabbath and Sunday in the Post-Apostolic Church," in From Sabbath to Lord's Day, ed. D.A. Carson (Grand Rapids: Zondervan, 1982) 251-298, at 278279.

20 Origen seems to be citing Jeremiah 17:21 or 22 or 24 from memory (see too his citation of Exodus 16:29 in the next line); see his commentary on Jeremiah 17:24-27 in the GCS edition (Origenes Werke 3 ed. E. Klostermann [1901] p. 202.) Doutreleau suggests Origen is citing Nehemiah 13:19. 
Origen means neither the seventh nor the first day of the week, but rather the whole Christian life. A Jew devotes one day a week to God, but a Christian devotes an entire lifetime. This is the true Sabbath that God desires, and this is the Sabbath that is observed by Christians in fulfillment of Exodus 16:29 and other biblical verses. This argument will recur regularly in later Christian authors. ${ }^{21}$

The Jews, of course, do not accept this interpretation of Exodus 16:29, but even they realize that the verse cannot be read literally. In another passage Origen writes more fully: 22

Indeed, what could be more impossible than the observance of the Sabbath according to the letter of the law, as we have already often discussed? For it is commanded not to go out of the house, not to move from one's place, and to carry no burden. Because the Jews, who observe the law according to the flesh, also regard these things as impossible, they contrive certain inept and ridiculous interpretations by which to seem to repair the impossible aspect of the law.

Even the Jews, Origen says, realize that the biblical commands not to go out of the house, not to move from one's place, and not to carry a burden on the Sabbath, are impossible to observe. The Jews solve this problem by contriving "inept and ridiculous interpretations" of the relevant biblical passages. We turn now to the Jewish interpretation of Exodus 16:29.

\section{(B) The Jewish interpretation of Exodus 16:29}

Therefore, those of the circumcision, and all those who maintain that nothing more than the literal is signified (by Scripture), do not seek the explanation for some matters, such as the goat-stag, the griffin, and the vulture; while on other matters they talk nonsense, arguing perversely, bringing forward cold traditions, as for instance when they say, in reference to the Sabbath, that each one's place is two thousand cubits.

Origen says that the Jews have nothing to say to, and no interest in, his arguments from the goat-stag (an imaginary creature), the griffin (an animal never caught by humans), and the vulture (an inedible bird). In his previous paragraph Origen had adduced these animals to prove that the biblical laws that mention them,

\footnotetext{
${ }^{21}$ I agree with Bauckham's interpretation of the passage. For the argument that the entire Christian life is the fulfillment of the true Sabbath, an argument that first appears in Justin, Dialogue with Trypho 12.3, see the passages collected by Willy Rordorf, Sunday: The History of the Day of Rest (Philadelphia: Westminster, 1968) 103-105, citing H. Dumaine in Dictionnaire d'archéologie chrétienne et de liturgie 4,1 (1921) 918-929.

22 Origen, Commentary on Romans 6.12 (vol. 2 p. 524 ed. Hammond Bammel = PG 14.1094): Quid enim tam impossibile, quam sabbati observatio secundum litteram legis, ut in multis saepe iam diximus? Iubetur enim non exire de domo, non se movere de loco suo, nihil oneris levare. Quae quoniam impossibilia vident Iudaei, qui secundum carnem legem observant, inepta quaedam et ridicula commentantur, quibus impossibilitatem legis sarcire videantur. My translation is based on Thomas Scheck, Origen Commentary on the Epistle to the Romans (The Fathers of the Church vols. 103-104; Catholic University of America, 2001-2002) 2. 48.
} 
and by extension all biblical law, cannot be understood literally (see above). Like Origen, I too cannot find any Jewish reflection on the practicability of the laws that refer to these animals. This problem did not bother Jewish exegetes. ${ }^{23}$

On Exodus 16:29, however, the Jews have what to say. They adduce their "cold (that is, lifeless, vain, silly ${ }^{24}$ ) traditions" according to which the biblical command let none of you go out from his place on the seventh day means that no Israelite is to venture forth more than two thousand cubits on the Sabbath. This Jewish tradition has three components: (1) the idea that travel on the Sabbath is prohibited beyond a given distance; (2) the identification of that distance with 2000 cubits; and (3) the interpretation of the phrase from his place in Exodus 16:29 as an allusion to the 2000 cubit Sabbath limit.

The origins of this Jewish tradition, at least its first two points, reach back to the second temple period. (1) The idea of a Sabbath limit (what the rabbis would call tehum Shabbat, the "Sabbath limit" or "Sabbath boundary"25) is mentioned in Acts 1:12, which reports that the Mount of Olives is "near Jerusalem, a Sabbath day's journey away." (2) The identification of the Sabbath limit with 2000 cubits appears in the Damascus Covenant and in at least one other Qumran text; it is widely attested in rabbinic literature. ${ }^{26}$ Point (3), which finds an allusion to the 2000 cubit limit in Exodus 16:29, specifically the phrase from his place, is attested in numerous rabbinic texts. ${ }^{27}$

This last point strongly suggests that Origen derived his information about this Jewish tradition from a rabbinic Jew, since the association of the 2000 cubits with Exodus 16:29 is quintessentially rabbinic; it is not securely attested anywhere in antiquity in any pre-rabbinic Jewish document. ${ }^{28}$ Confirmation that Origen's informant

\footnotetext{
23 The Sifra on the opening of Leviticus 11 (Shemini Parshata 2 p. 48a ed. Weiss = Vatican facsimile ed. Finkelstein p. $204=$ trans. Neusner 2.152) argues that among the animals that may be eaten are hybrids that are the offspring of cross-breeding. A Yemenite Midrash of the fifteenth century glosses this text with a reference to the koy, the rabbinic equivalent of the goat-stag (see note 6 above). See Midrash HaHefez, ed. M. Havatzelet vol. 2 p. 58 (cited by Torah Shelemah vol. 28 p. $55 \mathrm{sec} 9$ ). I do not think that this midrash has anything to do with Origen.

24 PGL s.v. psykhros. Rufinus translates inanes.

${ }^{25}$ M. Eruvin 5:5 and Sotah 5:3. De Lange 40 confuses tehum Shabbat with eruv.

${ }^{26}$ Covenant of Damascus 10:21 (1000 cubits; perhaps an error) and 11:5-6 (2000 cubits); 4 Q264a 1 line 1 (as restored; 1000 cubits) ; 4Q265 no. 7 line 5; M. Sotah 5:3. For an annotated edition of 4Q264a, see Vered Noam and Elisha Qimron, "A Qumran Composition on the Laws of the Sabbath," Tarbiz 74,4 (5765/2005) 511-546.

27 Two main sets of passages. First: Y. Eruvin 3:4 (21a); Y. Pesahim 6:1 (33b); B. Eruvin 17b. Second: Y. Eruvin 4:1 (21d); B. Eruvin 51a; Mekhilta Beshalah Vayasa 5 p. 170 Horovitz-Rabin; Mekhilta de Rabbi Shimeon bar Yohai Beshalah p. 114 lines 18-19 ed. Epstein-Melamed. See too Sifrei Zuta on Numbers 15:32 p. 287 and T. Eruvin 3(4).11 p. 101 ed. Lieberman with Tosefta K'Fshuta ad loc. 347-348.

${ }^{28}$ Most modern scholars see Exodus 16:29 as the source for the rule of Sabbath limits; there is room for doubt. None of the second temple period texts that refer to a Sabbath limit in general or to the specific limit of 2000 cubits (see note 26), mentions or even alludes to Exodus 16:29. 4Q421 12 line 4 (as restored) seems to paraphrase part of Exodus 16:29 but the restoration is uncertain (see Noam and Qimron,
} 
was a rabbinic Jew comes from a passage in one of the epistles of Jerome (ca. 345-420) who writes as follows: ${ }^{29}$

How many are the traditions of the Pharisees, which today they call deuterôseis, and how foolish are their fables, I am unable to explicate. For not even the magnitude of a book suffices, and many of their traditions are so disgusting that I am embarrassed to tell them. Nevertheless, I shall tell one, just to shame that inimical nation. They have made their greatest sages the leaders of their synagogues, and they are charged with the disgusting task of determining by taste, if they are unable to discern by the eyes alone, whether the blood of a virgin or a menstruant is pure or impure. Furthermore, because it is comanded that on the days of the Sabbath each one shall sit in his house and not go out and not walk from the place in which he lives, whenever we begin to reprove them that according to the literal sense (of Scripture) they should not lie down or walk or stand but only sit, if they wish to observe the commandments, they are accustomed to reply by saying, "Barachibas and Simeon and Helles our teachers have handed a tradition to us that we may walk 2000

\footnotetext{
"Qumran Composition"). Even the Mishnah does not allude to Exodus 16:29 in this connection. I would suggest that the prohibition of going on a journey on the Sabbath, which was known, among others, to Jubilees 50.12 and Josephus, AJ 13.252 (Doering, Schabbat 87-91 and 493-495), and does not necessarily have anything to do with Exodus 16:29, is the source of the idea of Sabbath limits. If I may be permitted to conjecture, the legal logic went something like this. Tradition declares that a journey is prohibited on the Sabbath. When does a journey begin? Once one has left one's city. Scripture shows (Numbers 35:4-5) that a city's territory extends 2000 cubits beyong its walls; hence 2000 cubits beyond the walls is the Sabbath limit. This seems to be the logic presumed by R. Aqiva in M. Sotah 5:3. The whole package, in typical rabbinic manner, was then attached to Exodus 16:29, which as a result became the subject of polemics and rival interpretations from antiquity to the middle ages. If I am right, point (3) reveals that Origen's informant knew the rabbinic reading of Exodus 16:29, strongly suggesting that he was a rabbinic Jew; I return to this point in my conclusion. If I am wrong point (3) does not necessarily establish the rabbinic provenance of Origen's informant, since many learned Jews, not just rabbinic sages, would have associated that verse with the law of Sabbath limits, and had been doing so since second temple times. For an excellent statement of the argument that Exodus 16:29 is the scriptural source of the Sabbath limit rule (again, just to be clear, this is the position that I am questioning), see the article by Rosenthal cited above in 17, which in turn has largely shaped the discussions in Schiffman 90-98 and Doering 87-94. On Exodus 16:29 see further below note 39 .
}

${ }^{29}$ Jerome Epistle 121 (Ad Algasiam).10 (PL 22.1033ff; CSEL 56.48-49): Quantae traditiones pharisaeorum sint, quas hodie deuterôseis vocant, et quam aniles fabulae, revolvere nequeo. Neque enim libri patitur magnitudo et pleraque tam turpia sunt, ut erubescam dicere. Dicam tamen unum in ignominiam gentis inimicae: praepositos habent synagogis sapientissimos quosque foedo operi delegatos, ut sanguine virginis sive menstruatae mundum vel immundum, si oculis discernere non potuerint, gustatu probent. Praetera, quia iussum est, ut diebus sabbatorum sedeat unusquisque in domo sua et non egrediatur nec ambulet de loco, in quo habitat, si quando eos iuxta litteram coeperimus artare, ut non iaceant, non ambulent, non stent, sed tantum sedeant, si velint praecepta servare, solent respondere et dicere: 'Barachibas et Symeon et Helles magistri nostri tradiderunt nobis ut bis mille pedes ambulemus in Sabbato' et cetera istius modi, doctrinas hominum praeferentes doctrinae dei. Non quo dicamus sedendum esse semper in sabbato et de loco, in quo quis fuerit occupatus, penitus non recedendum sed quo id, quod inpossibile legis est, in quo infirmatur per carnem, spiritali observatione conplendum sit. 
feet on the Sabbath," and other things of this sort. They prefer the teachings of humans to the teaching of God [cf. Mark 7:7-8]. (The point of my argument is) not that we should say that one must always sit on the Sabbath and not depart in the slightest from the place which one has occupied, but (my point rather is to show) that whatever part of the law is impossible, weakened by carnal interpretation - that part is to be fulfilled by spiritual observance.

In order to embarrass "the Pharisees" of his time, who are the rabbinic sages, Jerome adduces two legal traditions. The first, which concerns women's blood and the means for determining its impurity, is not relevant for our purposes. ${ }^{30}$ The second tradition is an explication of Exodus 16:29. Like Origen, Jerome reproves the Jews: if they really wish to observe the scriptural law "they should not lie down or walk or stand but only sit" on the Sabbath. Like Origen Jerome regards this as an impossible demand. ${ }^{31}$ The Jews respond to Jerome much as they had responded to Origen a century and a half earlier: Exodus 16:29 means "that we may walk 2000 feet on the Sabbath." Whether Jerome confused "feet" for "cubits," or whether his Jewish interlocutors did so, does not much matter for our purposes; this is clearly the same tradition that Origen cited. 32 Jerome's Jewish interlocutors, however, add an important piece of information. This tradition derives from "Barachibas and Simeon and Helles our teachers." Lurking behind these names are sages of the Mishnah, (apparently R. Aqiva, Shammai, and Hillel). ${ }^{33}$ Jerome and his Jewish informants attribute to latter day Pharisees, that is, the rabbinic sages, the tradition that Exodus 16:29 refers to the 2000 cubit Sabbath limit. We may assume that it was a rabbinic Jew, sage or not, who told Origen that Exodus 16:29 alludes to the Sabbath limit of 2000 cubits.

\section{(C) Dositheus the Samaritan and others on Exodus 16:29.}

Others, however, among whom is Dositheus the Samaritan, condemning such an interpretation, believe that in the position in which one was caught on the Sabbath day one is to remain until evening.

Rufinus paraphrases as follows:

Others, however, among whom is Dositheus the Samaritan, condemn interpretations of this kind and yet themselves posit something still more ridiculous, namely, that in whatever posture or place or position a person is

\footnotetext{
${ }^{30}$ Here too Jerome's testimony intersects (polemically, to be sure) with rabbinic lore; see Charlotte Elisheva Fonrobert, Menstrual Purity: Rabbinic and Christian Reconstructions (Stanford University Press, 2000) 103-127, esp. 115-116.

${ }^{31}$ See above note 16 re Jerome.

32 The connection between this passage of Jerome and our passage of Origen has often been noted. See e.g. Emil Schürer, History of the Jewish People in the Age of Jesus Christ, rev. G. Vermes et al. (Edinburgh: T \& T Clark, 1973-1987; four volumes) 2.472 n. 46 and Doering, Schabbat 150 n. 163.

${ }^{33}$ R. Aqiva, Shammai, and Hillel also appear (along with several others) in Jerome's commentary on Isaiah 8:14 (CCSL 73.116).
} 
found on the Sabbath day he should remain thus until evening; that is, if sitting he should sit all day; if lying down, he should lie down all day.

Before we turn to the identity of this Dositheus, let us first try to understand what he means when he says "that in the position in which one was caught on the Sabbath day one is to remain until evening." What does "position" (skhêma) mean? Rufinus understands the word to mean "posture or place or position," so that according to Dositheus Exodus 16:29 demands that, if at the beginning of the Sabbath one was sitting, one would sit all day; if at the beginning of the Sabbath one was lying down, one would lie down all day. ${ }^{34}$ This interpretation is certainly possible - elsewhere too in Origen skhêma can mean "posture" 35 - and given Rufinus' familiarity with Origen's works and usage, I suppose that his interpretation should be followed in the absence of any compelling argument to the contrary. There are, of course, other, if less attractive, possibilities. Sometimes Origen uses skhêma to mean "outfit, clothing" 36 ; if we apply that meaning here, Dositheus is claiming that Exodus 16:29 forbids changing clothes on the Sabbath. This seems unlikely; I do not see how anyone could construe the verse as a prohibition of changing clothing. Some have suggested that skhêma here means "social condition," others "state of mind," but both of these suggestions seem far from the plain meaning of the word and the scriptural verse. ${ }^{37}$ So we are left with Rufinus.

Rufinus' interpretation raises a serious problem, however. In (A) Origen argues that Exodus 16:29 cannot be interpreted literally "since no living creature is able to sit for a whole day and not move from sitting." And yet here in (C), Origen quotes Dositheus (and others) according to whom Scripture demands postural immobility for the duration of the Sabbath! If this is an impossibility in (A) it should also be an impossibility in (C). Rufinus solves this problem by adding the phrase "and yet themselves posit something still more ridiculous," which has Origen condemning Dositheus' interpretation in (C) just as he had condemned the literal interpretation in (A). Alas, these words are missing from the Greek of the Philocalia, and I do not know how to solve this problem. Perhaps, if I may offer an alternative suggestion, Origen understands Dositheus not as advocating normative practice but as polemicizing against Jewish practice. In (A) Origen argues that the Jews do not follow the literal meaning of Exodus 16:29; perhaps in (C) Dositheus is doing the same thing. If the Jews wish to observe Exodus 16:29 they should spend the Sabbath at home maintaining

\footnotetext{
34 The verb katalambanein, translated here "was caught," perhaps suggests that Dositheus thought, as the Jews did, that the Sabbath begins at nightfall (late Friday afternoon). The verb is often used in the sense of night or darkness "coming upon" someone; see BDAG def 2c.

35 Origen, De Oratione 31.1 (holding one's hands aloft).

36 Origen, Contra Celsum 5.50, based on Josephus, AJ 11.334, as noted by Stanley J. Isser, The Dositheans (Leiden: Brill, 1976) 27 n. 36.

37 "Social condition" is suggested by Isser, The Dositheans 26. R.P.C. Hanson paraphrases the passage as follows, "Others, of whom is Dositheus the Samaritan, say that the command means that everyone is to remain in the same state of mind during the Sabbath"; see R.P.C. Hanson, Origen's Doctrine of Tradition (London: SPCK 1954) 153.
} 
exactly the same posture they had when the Sabbath began. Each polemicizes against Jewish practice; Jerome too has the same polemic, as we have seen above. According to Rufinus' interpretation, Dositheus advocated a rigorist stance in observing Sabbath law. ${ }^{38}$ According to the alternative that I am proposing (very tentatively), Dositheus polemicized against the Jewish reading of scripture, and as to his own Sabbath practice we know nothing. ${ }^{39}$ The advantage of my interpretation is that it absolves Origen of logical inconsistency; is this a sufficiently compelling reason to abandon Rufinus' interpretation? I am not sure.

The identification of this Dositheus is another problem. In five other passages Origen refers to Dositheus the Samaritan, a self-proclaimed messiah and son of God of the first century CE. His followers, the Dositheans, have all but disappeared, says Origen; scarcely thirty remain. According to Origen Dositheus closely resembles Simon Magus, that other Samaritan heresiarch. ${ }^{40}$ The problem here is that it is difficult to understand how and why a Samaritan messiah and son of God would advocate (as Rufinus understands the passage) a rigorist stance on Sabbath law or (as I have proposed) would attack Jews for their interpretation of Exodus 16:29. None of Origen's other passages about Dositheus contains anything that would lead us to expect such a tradition. Over a hundred years ago Samuel Krauss suggested that there were several different Dositheoi, and that the Dositheus of our passage, the advocate of rigorous Sabbath law, is not to be identified with the Samaritan heresiarch and messianicpretender who is the subject of Origen's polemic elsewhere. ${ }^{41}$ Recent scholarship rejects this reconstruction, but we are left with the problem that the testimony of our passage about Dositheus does not readily cohere with the testimony of Origen's five other passages.

\section{(D) The interpretation of Jeremiah 17:21}

(D) Further, the verse not to lift a burden on the Sabbath day (Jeremiah 17:21) is impossible.

\footnotetext{
38 This interpretation might perhaps receive some support from the $14^{\text {th }}$ cent Samaritan chronicler Abu'l Fath, who says that the disciples of Dusis (=Dositheus) "did not travel from house to house on the Sabbath day"; see Isser, Dositheus 79.

${ }^{39}$ If I am right (see note 28 above), Dositheus, like Origen, is polemicizing in the first instance against rabbinic sages, for they are the ones who attempted to justify Jewish practice by appeal to Exodus 16:29. On the other hand, if this Dositheus is indeed a figure of the first century $\mathrm{CE}$, and if Origen is citing him correctly, and if we are interpreting Origen correctly - three debatable assumptions -- then we have evidence for the use of Exodus 16:29 in Jewish legal debates even before the emergence of the rabbis in the second century, thus refuting my scepticism.

40 Isser, Dositheans 25-33; Reinhard Pummer, Early Christian Authors on Samaritans and Samaritanism (TSAJ 92; Mohr Siebeck, 2002) 43-44 (who follows Isser). The main passages about Dositheus are Contra Celsum 1.57 and 6.11 .

${ }^{41}$ Samuel Krauss, “Dosithée et les Dosithéens," REJ 42 (1901) 27-42, discussed and rejected by Isser, Dositheans 115-116.
} 
Jeremiah 17:21-27 is an important passage in the development of Sabbath law. Here are excerpts from the passage in Hebrew and Greek, with translations of each. ${ }^{42}$ כא( כה אמר יקוק השמרו בנפשותיכם ואל תשאו משא ביום השבת והבאתם בשערי ירושלם כב( ולא תוציאו משא מבתיכם ביום השבת וכל מלאכה לא תעשו וקדשתם את יום השבת... כד( והיה אם שמע תשמעון אלי נאם יקוק לבלתי הביא משא בשערי העיר הזאת ביום השבת ות בה בו כל מלאכה... ולקדש את יום השבת לבלתי עש

כז) ואם לא תשמעו אלי לקדש את יום השבת ולבלתי שאת משא ובא בשערי ירושלם ביום השבת...

(21) Thus says the Lord: For the sake of your lives, take care that you do not bear a burden on the Sabbath day or [alternative translation: and] bring it in through by the gates of Jerusalem. (22) And do not take a burden out of your houses on the Sabbath day or do any work, but keep the Sabbath day holy ... (24) But if you listen to me, says the Lord, and bring in no burden through the gates of this city on the Sabbath day, but keep the Sabbath day holy and do no work on it ... (27) But if you do not listen to me, to keep the Sabbath day holy, and to carry no burden or [alternative translation: and] enter [alternative translation: bring it in] through the gates of Jerusalem on the Sabbath day ...

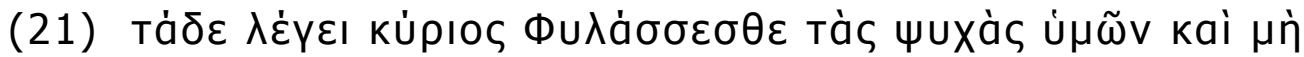

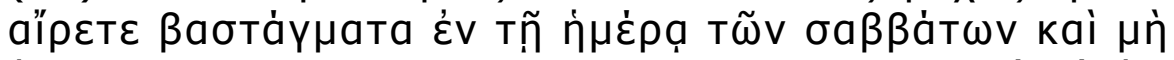

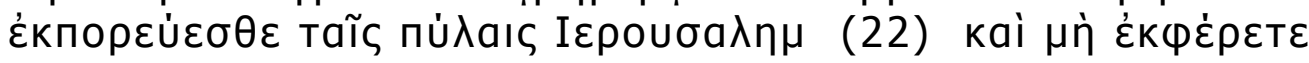

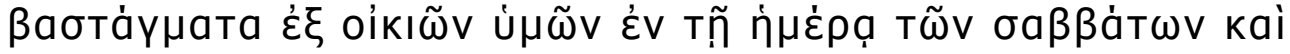

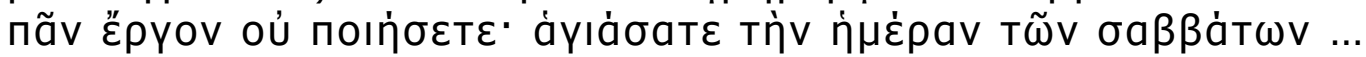

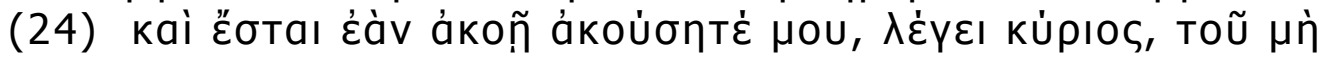

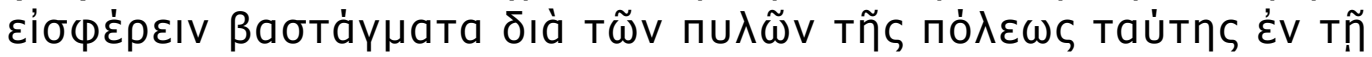

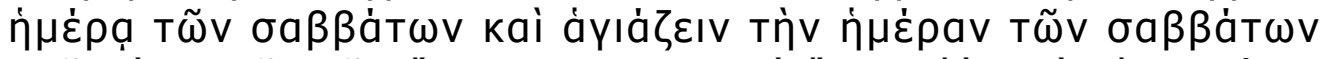

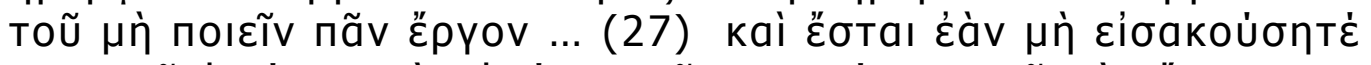

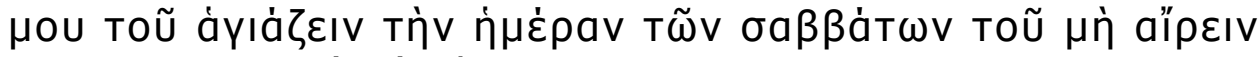

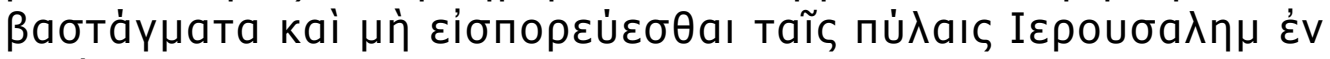

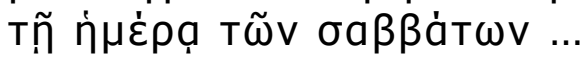

(21) This is what the Lord says: Watch your souls, and do not lift burdens on the day of the Sabbath, and do not go out ${ }^{43}$ by the gates of Jerusalem. (22) And do not carry burdens out of your houses on the day of the Sabbath, and you shall not do any work; keep the day of the Sabbath holy ... (24) And it shall be if you hear me by hearing, says the Lord, so as not to bring in burdens through the gates of this city on the day of the Sabbath and to keep the day of the Sabbath holy so as not to do any work

\footnotetext{
42 My translation of the Hebrew is based on the NRSV; my translation of the LXX is based on A New English Translation of the Septuagint, ed. A. Pietersma and B. Wright (Oxford University Press, 2007) 896897.

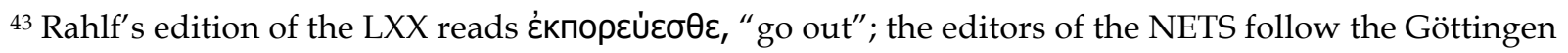

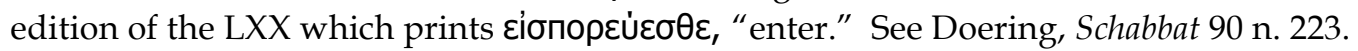


... (27) And it shall be if you do not listen to me to keep the day of the Sabbath holy, so as not to lift burdens and not to enter by the gates of Jerusalem on the day of the Sabbath ...

A full exegesis of this passage will take us far afield; what is important for our purposes is the dual prohibition of carrying a burden on the Sabbath and bringing it to or through the gates of Jerusalem. Jeremiah uses three different verbs to denote this forbidden activity: do not bear a burden (vs. 21), do not take out a burden (vs. 22), and do not bring in a burden (vs. 24). There is no prohibition here of traveling on the Sabbath; Jeremiah clearly implies that one may go out of one's house to or through the gates of Jerusalem, as long as one is not carrying a burden. If Jeremiah knew Exodus 16:29 he either did not interpret it literally or did not regard it as an eternal Sabbath ordinance. ${ }^{44}$ In context it is likely that when Jeremiah says burden he means "merchandise for sale"; this is how the passage was understood by Nehemiah (13:14-21)..$^{45}$ By the time the rabbis enter the scene the concept of "burden" was broadened to include any object. These verses of Jeremiah, especially Jeremiah 17:22, are regularly cited by rabbinic texts to document the prohibition of carrying ("taking out") an object ("a burden") from a private domain ("out of your houses") to a public domain ("the gates of Jerusalem").46

Origen cites only 17:21, but surely was familiar with the entire paragraph in Jeremiah. Therefore when he refers to the prohibition of "lifting burdens" (aîpعiv ßабта́үната) we may be sure that he refers to the prohibition of "carrying" or of "removing" objects from the house to the outside. ${ }^{47}$ This much is clear; what is not clear

\footnotetext{
${ }^{44}$ Kugel, Traditions of the Bible 645.

45 Whether this passage of Jeremiah is genuine Jeremiah, or, as is widely assumed, a post-Jeremianic interpolation (related to Nehemiah 13:14-21), is not my concern here; see e.g. Gnana Robinson, The Origin and Development of the Old Testament Sabbath (Beiträge zur biblischen Exegese und Theologie 21; Peter Lang, 1988) 195-199.

${ }^{46}$ Y. Shabbat 1:1 init. (2b) //Y. Shevuot 1:1 (32c); B. Beitzah 12a; B. Horayot 4a. Some rabbinic texts are not comfortable using a passage from a prophet to document a legal prohibition; they cite a verse of the Torah instead. B. Shabbat $96 \mathrm{~b}$ bases the prohibition on Exodus 36:6. More germane for us are the attempts to base the prohibition on a creative punctuation of Exodus 16:29. See B. Eruvin 17b, esp. the Tosafot s.v. lav she nitan, which quotes an alternative reading in B. Horayot $4 \mathrm{a}$ according to which the cited biblical verse is not Jeremiah 17:22 but Exodus 16:29. This too is the version of the Munich manuscript and other sources; see Torah Shelemah on Exodus 16:29 vol. 14 p. 233 section 172. Joseph M. Baumgarten notes that at least one Qumran text seems to be familiar with the same creative punctuation of Exodus 16:29; see Baumgarten, "The Laws of the Damascus Document - Between Bible and Mishnah," in The Damascus Document A Centennial of Discovery, ed. Joseph M. Baumgarten, Esther Chazon, Avital Pinnick (Brill 2000) 17-26, at 21-22.

47 "To carry" and "to remove" in fact are normal meanings of the verb airein; see the standard lexica, and for a good example see John 5:9-12. See also the passage from Origen's Commentary on Romans 6.12.2 cited above at note 22. I have dilated upon this point because I am trying to show that Origen is referring to the prohibition of carrying an object out of the house, not to the prohibition of lifting/moving muqtzah objects within the house. [What is muqtzah? If an object has no permitted use on the Sabbath (e.g. a saw, a hammer); if on the eve of the Sabbath an object's owner could not have foreseen a use for it on the Sabbath and hence had no intention of using it; if an object did not yet exist or was not yet in one's possession on the eve of the Sabbath - any such object is said by the Talmud to be muqtzah, "set aside
} 
is why Origen says that the observance of this prohibition is "impossible." Why is it impossible to refrain from carrying burdens outside the house on the Sabbath? Perhaps Origen simply means that the distinctions introduced by the rabbinic sages (see E) are impossible to justify or observe, hence the prohibition itself, when read rabbinically, is impossible. Or, we may suggest in the light of (E), perhaps Origen thinks that wearing clothing would be a violation of the prohibition, if read literally, for can not clothing be construed as a burden? ${ }^{48}$ And if wearing clothing violates the prohibition, then surely the prohibition is impossible. One wishes that Origen had explained himself more fully.

\section{(E) The Jewish interpretation of Jeremiah 17:21}

Therefore the teachers of the Jews have come to endless argumentation, asserting that one kind of footwear is a burden but another is not, and that a sandal with nails is a burden but one without nails is not, and that what is carried just-so on one shoulder is a burden but not what is carried on both.

According to Origen the teachers of the Jews introduce a series of impossible distinctions in their interpretation of Jeremiah 17:21: (a) some kinds of footwear are a burden, others are not; (b) nailed sandals are a burden, unnailed sandals are not; (c) an item carried on one shoulder is a burden, but not an item carried on two. Rufinus paraphrases the passage as follows:

For from these words the teachers of the Jews fall into endless fables, as the holy apostle says (1 Timothy 1:4), saying that it is not reckoned a burden if one has shoes (calciamenta) without nails, but that it is a burden if one has shoes (galliculas) with nails; and if one should carry something on one shoulder, they deem it a burden, but if one should carry it on both, they say it is not a burden.

Rufinus has made various changes. He has introduced the reference to 1 Timothy; he has transferred the distinction between nailed and unnailed footwear from sandals to shoes; he has introduced two different terms for shoes; and he has eliminated any reference to sandals. Once again, as I argued above, I think that we need to take Rufinus seriously as an interpreter of Origen, but we may assume that the Greek text of the Philocalia brings us closer to what Origen wrote than does the Latin of Rufinus. I shall discuss in turn each of the three distinctions that Origen attributes to the teachers of the Jews.

\section{(a) one kind of footwear is a burden but another is not.}

\footnotetext{
(from use)" and may not be moved from one place to another, even within one's home. The Mishnah does not use the term muqtzah in this sense, but certainly has the concept.] Origen does not discuss muqtzah.

48 This is not a philological argument; neither the verb airein nor the noun bastagma implies or alludes to the wearing of clothing.
} 
The word translated "footwear" is hupodêma which can also mean either "shoe" or "sandal." 49 If it means "footwear," (a) functions as a header to (b): "one kind of footwear is a burden, but another is not, namely, a sandal with nails is a burden, but one without nails is not." Origen provides two specific examples of Jewish exegesis of the Jeremianic burden (nailed sandals, and carrying on one shoulder). If, however, hupodêma means "shoe," which seems to be how Rufinus understood the word, ${ }^{50}$ Origen provides three specific examples of Jewish exegesis of the Jeremianic burden (shoe, nailed sandals, and carrying on one shoulder). This is certainly possible, but I have not been able to find any ancient ${ }^{51}$ Jewish text that distinguishes one kind of shoe from another with respect to the law of the Sabbath; indeed it is hard to understand why any kind of shoe would be prohibited as a burden on the Sabbath. The Talmud discusses the prohibition of nailed sandals on the Sabbath, as we shall see in the coming paragraphs, but the Talmud does not discuss the prohibition of any kind of shoe. ${ }^{52}$ So, if hupodêma here means "shoe," Origen either is alluding to some otherwise unattested Jewish tradition or is making a mistake. Surely it is simpler to understand hupodêma as "footwear" and to see (a) as a general statement followed by the specific statement of (b).

\section{(b) a sandal with nails is a burden but one without nails is not}

Origen's text clearly and unmistakably intersects with Mishnah Shabbat 6:2. I present the text, a translation, and some explanatory notes.

המסומר בסנדל האיש יצא לא

מכה ברגלו שאין בזמן ביחיד ולא

המומחה מן שאינו בזמן בקמיע ולא בתפילין ולא

במגפיים ולא בקסדא ולא בשריון ולא

חטאת חייב אינו יצא ואם

A man may not go out [on the Sabbath] with nailed-sandals, or with a single sandal if he has no wound in his foot;

\footnotetext{
49 Thus e.g. modern translations of John 1:27 vary between "shoe" and "sandal." See Otto Lau, Schuster und Schusterhandwerk in der griechisch-römischen Literatur und Kunst (diss. Bonn, 1967) 130, "Mit hypodêma erfassen wir die allgemeinste Bezeichnung: das, was unter die Füsse bindet."

50 Rufinus distinguishes "shoes (calciamenta) without nails" from "shoes (galliculas) with nails." On gallicae (the philological ancestor of our "galoshes") see Lau 131; on p. 145 he classifies gallicae as sandals, whereas on p. 146-147 he classifies calcei as shoes. I lack the expertise to explain Rufinus.

51 Or medieval or modern, for that matter.

$52 \mathrm{~B}$. Shabbat $60 \mathrm{~b}$ explicitly limits the prohibition of nailed sandals to sandals alone, not shoes. The Yerushalmi might disagree, believing that the prohibition extends to nailed shoes too; see Y. Shabbat 6:2 (8a) mahu litnem (masmerim) al gabei sandal ehad ... mahu litnem al gabei man'al ehad which suggests parity between sandal and shoe. The Qorban Ha Edah emends the text to mahu litnem al gabei man'al, deducing that the prohibition applies only to sandals, not shoes, as in the Bavli. But the Yerushalmi proceeds to discuss sandals and shoes, treating them as equivalents. Still, our text of Origen (contrast Rufinus) does not have the prohibition of nails apply to shoes.
} 
or with phylacteries, or with an amulet, if it is not from an expert; or with a breast-plate, or with a helmet, or with greaves.

But if he went out, he is not liable to a Sin-offering.

Man: Mishnah Shabbat 6:2 and 4 deal with items that men may not wear, 6:1 and 3 with items that women may not wear.

Not go out: from one domain to another.

With a single sandal if he has no wound in his foot: If he has no obvious wound on his foot, people may suspect him of carrying the other sandal under his cloak.

An amulet: An amulet prepared by an expert amulet-maker would be permitted for the sake of healing (Mishnah Shabbat 6:10). An amulet prepared by a non-expert amulet maker is neither an aid to healing nor an ornament.

Breast-plate ... helmet ... greaves: Military gear is not ornamental; cf. Mishnah Shabbat 6:4.

But if he went out: Normally, inadvertent violation of a Sabbath prohibition incurs liability to a Sin-offering. In this case, however, if one inadvertently wore any of these items on the Sabbath while going from one domain to another, nevertheless, he is not liable to a Sin-offering, because the items listed in this paragraph are prohibited to be worn on the Sabbath only by rabbinic ordinance. In principle they may be worn on the Sabbath, except that for some unstated cause the rabbis prohibited it. Consequently, the prohibition of wearing one of these items is relatively minor and inadvertent taking out does not incur liability to a Sin-offering. The same law appears in 6:1.

A full discussion of all these laws will take us far afield, so I focus only on the nailed-sandals.

In Mishnaic law a person on the Sabbath is prohibited from taking an object from one domain to another, that is, from private space to public space, from public space to private space, or from one private space to another. The discussion of this prohibition of "taking out," sometimes called "going out," takes up the lion's share of Mishnah tractate Shabbat. Although carrying an object from one domain to another is prohibited, one may wear clothing on the Sabbath and go freely from one domain to another while doing so. Chapter six of Mishnah Shabbat deals with the question: what is clothing? What sorts of items may one wear on the Sabbath without violating the prohibition of "taking out"? 6:2 opens with the ruling that a man on the Sabbath may not go out, that is, go from one domain to another, while wearing nailed-sandals, that is, sandals with metal studs or cleats. The Mishnah specifies "man" because nailedsandals are footwear for men.

Why not? Why should a man not be allowed to wear nailed-sandals on the Sabbath while going from one domain to another? The Mishnah, as is its wont, does not explain. The final line of the Mishnah ("But if he went out, he is not liable to a Sinoffering") implies that this prohibition derives not from Torah law, the intentional violation of which would incur the death penalty, the unintentional violation of which would incur liability to a Sin-offering, but from rabbinic law, the violation of which incurs milder penalties. Still, why should there be a prohibition at all? 
The Talmudim are bothered by this question, and provide an explanation. Here is the Yerushalmi: ${ }^{53}$

Why did they [the Sages] make a decree against nailed-sandals?

Some say: because women would see its impression and miscarry.

And some say: because women would hear its sound and miscarry.

And some say: on account of the fact that they would jostle one the other and kill one the other.

The last of these three explanations is turned by the Bavli (60a) into three full-blown stories about panic, terror and death, all caused by the sight or sound of nailed-sandals. Roman soldiers wore nailed-sandals. ${ }^{54}$ The impression made by nailed-sandals in the ground or the sound of nailed-sandals marching along meant that Roman soldiers were operating in the vicinity - no wonder terror would ensue. Hence to minimize the danger of panic, the sages prohibited Jewish men from wearing nailed-sandals.

Both Talmudim are aware of a serious problem with this explanation. If the basis of the prohibition is public safety, what does that have to do with Sabbath law? The Bavli explains that the sages prohibited nailed-sandals on the Sabbath because a nailedsandal-induced stampede that led to the deaths of many Jews occurred on a Sabbath (!). This explanation is rather lame; that of the Yerushalmi is more intriguing:

If so [if the prohibition is a special decree on behalf of public safety, the sandals should be prohibited] even on a weekday!

[Answer:] A person does not usually have two [pairs of] sandals, one for the weekday and the other for the Sabbath.

Saul Lieberman explains as follows. The "real" reason for the prohibition of nailedsandals is public safety, but the sages (in the Mishnah) pretended that the prohibition had something to do with the Sabbath. Why? Because they had authority and influence among the people in matters concerning the Sabbath, and would more likely command popular assent if the people thought that they were expounding Sabbath law. By outlawing nailed-sandals on the Sabbath, the sages effectively outlawed them altogether, since most people could not afford separate pairs of sandals for the Sabbath and for weekdays. ${ }^{55}$ The Yerushalmi's interpretation is rather ingenious, but ultimately

\footnotetext{
${ }^{53} \mathrm{Y}$. Shabbat 6:2 8a. I can no longer recall, and consequently cannot credit, the source of the suggestion that ראשו be translated "its impression" (akin to רושמו).

54 See e.g. Josephus, Jewish War 6.85; Samuel Krauss, Talmudische Archäologie (Leipzig: G. Fock, 1910) 1.178 with note 683. Laborers also wore nailed sandals. See Rolf Hurschmann, "Nagel" and "Schuhe" in Der neue Pauly (Brill Online, accessed Harvard University 07 April 2008); James Diggle, Theophrastus Characters (Cambridge University Press, 2004) 218 (commentary on Theophrastus 4). For an illustration of nailed sandals, see Daremberg et Saglio, Dictionnaire des antiquités grecques et romaines 4,2.1389 (s.v. solea).

${ }_{55}$ Lieberman, Tosefta K'Fshuta Shabbat 64; Saul Lieberman, Hellenism in Jewish Palestine (NY: Jewish Theological Seminary, 1950) 139-140. Lieberman does not state unequivocally that he accepts the public safety argument as the "real" reason for the prohibition. He writes that the Sages sought to ban nailed sandals "for social or sentimental reasons." Is Lieberman suggesting that the public safety argument is also a cover for the "real" one, which is left concealed? (In which case, is Lieberman rejecting the relevance of the stories in the Bavli and the Yerushalmi? Such skepticism was atypical for him.)
} 
not satisfying, because the Mishnah does not provide the slightest hint that the prohibition of nailed-sandals derives from concerns about public safety. ${ }^{56}$

Origen suggests a much simpler and more natural explanation. Nailed-sandals may not be worn on the Sabbath because the wearer is carrying the nails, and consequently violating the prohibition of carrying a burden as stated by Jeremiah 17:21. Origen's statement is insufficiently detailed to let us determine whether the Jewish teachers think that the nailed-sandal is prohibited by Torah law, or, as the Mishnah suggests, only by rabbinic expansion. In either case, why should the nails be deemed a burden? Origen does not explain, and we can only speculate. Perhaps because nails are not necessary to the sandal - indeed, standard sandals in antiquity do not have studs or cleats $^{57}$ - they are deemed to be a burden. The wearer is moving the nails about for no purpose. ${ }^{58}$ Alternatively, the prohibition is based on the fear that the nails might fall out, and the wearer will pick them up and carry them. ${ }^{59}$ Whatever explanation we supply, the important point is the consonance between Origen's statement and the Mishnah's: according to the Mishnah, on the Sabbath one may not go out from one domain to another while wearing nailed-sandals; according to Origen the Jewish teachers say that a sandal with nails may not be worn on the Sabbath because it is a burden in terms of Jeremiah 17:21, that is, that it may not be worn outside the house. Both the Mishnah and Origen's Jewish teachers clearly imply that one may wear nailedsandals inside the house on the Sabbath and outside it during the week. ${ }^{60}$

If I have explained all this correctly, the Jewish teachers cited by Origen have given a better explanation of the law of Mishnah Shabbat 6:2 than have the Talmudim!

\section{(c) what is carried just-so on one shoulder is a burden but not what is carried on both.}

This phrase, too, clearly and unambiguously intersects with Mishnah Shabbat, in this case 10:3. I present text, translation, and some explanatory notes.

חייב כתיפו על או חיקו בתוך בשמאלו בין בימינו בין המוציא

קהת בני משא שכן

\footnotetext{
${ }^{56}$ Consequently modern scholars have suggested a number of other explanations; see Abraham Goldberg, Commentary to the Mishna Shabbat (Jerusalem: Jewish Theological Seminary, 5736/1976) 103; Hanan Eshel, "Nailed Sandals in Jewish Sources and in the Excavations of a Cave at Ketef Jericho," Zion 53 (5748 / 1988) 191-198 (Hebrew). I do not discuss here Lieberman's assumptions about rabbinic power.

${ }^{57}$ Lau, Schuster 91, "Es liegt auf der Hand, dass hauptsächlich Schuhwerk des täglichen Bedarfs durchgenäht wurde." On 91-94 Lau illustrates various types of nailed-soles.

58 For a rabbinic debate about moving objects on the Sabbath for no purpose, see M. Shabbat 17:4. Carrying objects on the Sabbath "in [or: by] the shoe, or in [or: by] the sandal" is not punishable according to M. Shabbat 10:3 (see below), but is prohibited.

${ }^{59}$ Cf. B. Shabbat 57a. This sort of explanation is characteristic of Bavli Shabbat.

${ }^{60}$ Tosefta Shabbat 4(5).8 p. 18 ed. Lieberman says that nailed-sandals may not be worn at all, even in the house, on the Sabbath.
} 


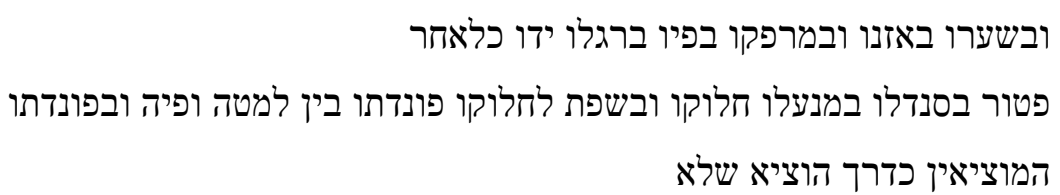

One who takes out [an object from one domain to another], whether by his right hand or by his left hand, in his bosom or on his shoulder - he is culpable; for thus was the manner of carrying by the sons of Kehat.

[One who takes out an object from one domain to another] on the back of his hand, or with his foot, or with his mouth, or with his elbow, or in his ear, or in his hair, or in his wallet while its mouth is downwards, or between his wallet and his shirt, or in the hem of his shirt, or in his shoe, or in his sandal - he is exempt,

since he has not taken it out in the manner of those that take out.

The prohibition of taking out from one domain to another is violated only if the object is carried the way that objects are normally carried.

On his shoulder: this is the reading of all the manuscripts. The Vilna edition of the Bavli reads כתפיו, "his shoulders."

For thus carrying on the shoulder was the manner of carrying the Tabernacle by the sons of Kehat: Numbers 7:9. Hence carrying on the shoulder is deemed "carrying." The various acts that the Levites performed in the wilderness in order to transport and set up the Tabernacle, and, according to the Talmud, the various acts performed by the priests in order to keep the Tabernacle functioning, are the mirror-image paradigms of the labors prohibited on the Sabbath (7:2). Whatever labor they did, is defined as labor and therefore is prohibited on the Sabbath; whatever labor they did not do, is not defined as labor and therefore is permitted on the Sabbath, or at least incurs no liability. See Mishnah Shabbat 11:2 and 12:3.

Hem: or "border."

In the manner of those that take out: that is, none of these is a "proper" act of carrying, hence none of these incurs liability for carrying from one domain to another.

As we have already seen, according to the Mishnah carrying an object from one domain to another on the Sabbath is prohibited. Mishnah Shabbat 10:3 adds the important proviso that the act of carriage is punishable only if the object were carried "normally," that is, if the object were carried in the manner that such an object is normally carried. If one were to carry an object from one domain to another in a wildly original or creative manner, this person would not be liable to punishment, even if Torah-true and God-fearing people would no doubt refrain from such behavior. In other words, the act is prohibited but is not liable to punishment. What, then, is a "normal" act of carrying? Carrying with one hand or on the shoulder is considered "normal" carriage, hence prohibited and liable to punishment, whereas carrying something by the mouth or the ear (the Mishnah goes on to list other examples) is not considered "normal" carriage, hence it is prohibited even if it is not liable to punishment. And how do we know that carrying on the shoulder is deemed to be "normal" carriage? From the scriptural report about the Levite clan of Kehat, who carried the tabernacle in the wilderness "on the shoulder," proof that this is a normal way to carry. 
Hence, when Origen says that according to the Jewish teachers "what is carried just-so on one shoulder is a burden," he is in full agreement with the ruling found in Mishnah Shabbat 10:3. The Mishnaic parallel strongly suggests that houtôsi in this sentence be translated "just so," that is, "in a particular way," in this case, "in a normal manner." 61 I concede that the more natural way to translate the phrase would be "and likewise, what is carried on one shoulder is a burden," but I would like to think that the Mishnaic source allows us to see something in Origen's Greek that otherwise we would not see. (Rufinus, for example, didn't see it.) But I do not insist on this point.

What is more important is that Origen misconstrues the Mishnaic law when he says "but not what is carried on both." This is wrong. ${ }^{62}$ The Mishnah, of course, means that carriage even by one hand is punishable, all the more so carriage by two hands; carriage on the shoulder is punishable, whether on one shoulder or all the more so on two -- provided that the object is normally carried thus. Origen's mistake apparently arose from an overly literal if ill informed reading of the Mishnaic, translated above "his shoulder." Origen (or his informant) understood this to be a singular noun; indeed it is a singular noun, but in Mishnaic Hebrew this singular noun refers to either one shoulder or two. ${ }^{63}$ Thus, M. Hagigah 1:1 reads, "Who is [deemed] a minor [so as to be exempt from the commandment of going up to Jerusalem on pilgrimage]? Whoever is not able to ride his father's shoulder." As any parent can attest, little children ride on two shoulders, not one, but the Mishnah says כתיפיפו passages we can't be sure whether the intended meaning of כתיפו is one shoulder or two - not that it much matters since, as in our Mishnah, the halakhah is the same either way. ${ }^{65}$ In sum: when Mishnah Shabbat 10:3 said כתיפו על it meant "on the shoulder, whether one or two." Origen (of his informant), however, took the phrase literally, as if it meant "on his shoulder (singular), but not on his shoulders (plural)." This mistake shows that Origen (or his informant) knew this law in a formulation very similar to, if not identical with, the formulation that appears in our Mishnah.

\section{Conclusions: Sabbath Law and Mishnah Shabbat in Origen De Principiis}

The paragraph that stands at the heart of this article is one of Origen's most detailed discussions of Jewish law, if not the most detailed. ${ }^{66}$ He refers to two laws of the Sabbath, one attached to Exodus 16:29 and the other attached to Jeremiah 17:21. According to the former, on the Sabbath one must remain within 2000 cubits of one's

\footnotetext{
${ }^{61}$ De Lange, Origen and the Jews 93, translates "and that what is carried in a certain way on one shoulder is a burden, but what is carried on both shoulders is not."

${ }^{62}$ De Lange too has misunderstood this point; see Origen and the Jews 40.

${ }^{63}$ I owe this acute observation to my colleague Bernard Septimus.

${ }^{64}$ The manuscripts of M. Hagigah 1:1 read אביו של כתיפו על לרכוב יכול שאינו כל קטן איזהו. The Vilna edition reads כתפיו, just as it does in Shabbat 10:3.

65 M. Kilayim 9:4; Bava Metzia 7:3; Negaim 13:9. The singular meaning (one shoulder) apparently is meant at M. Pesahim 5:9; Bikkurim 3:4,6.
}

${ }^{66}$ De Lange, Origen and the Jews 39-40. 
place. According to the latter, a burden on the Sabbath may be permitted or prohibited to be carried depending on the manner in which it is carried (on one shoulder is prohibited, on two is permitted) and on the nature of the burden (a nailed-sandal may not be worn, a sandal without nails may be worn).

Origen correctly attributes the first of these laws to "tradition" (paradosis); it is attested in second temple times. However, he knows this tradition in its rabbinic form, since he associates the 2000 cubit limit with Exodus 16:29; this association is widely attested in rabbinic texts, but unattested in pre-rabbinic texts. Origen attributes the second of these laws to "the teachers of the Jews" (hoi tôn Ioudaiôn didaskaloi), and we may be sure that he means the rabbinic sages since these rulings appear in Mishnah Shabbat (and in no document before Mishnah Shabbat). ${ }^{67}$

How did Origen come to know this bit of rabbinic lore, the association of the 2000 cubit Sabbath limit with Exodus 16:29, and this bit of rabbinic law, the Mishnaic rules about carrying on one shoulder and wearing nailed sandals? Surely Origen had a rabbinic informant. Origen must have had a conversation with him about Sabbath law, in the course of which he learned these rabbinic rulings which he then used for his polemical purposes. There is no sign that Origen's rabbinic informant knew the book that we call the Mishnah ${ }^{68}$; instead he might have known rulings out of which the Mishnah was being constructed, and he might have known them orally. Precisely when the Mishnah book emerged is not known; it is usually attributed to somewhere in the period 200-240 CE. ${ }^{69}$ Origen wrote the De Principiis in the early 220s.

The identity of this anonymous unmentioned Jewish informant is, obviously, beyond our grasp..$^{70}$ In another passage of the De Principiis Origen explicitly refers to

67 Elsewhere in Origen's writings this phrase (hoi tôn Ioudaiôn didaskaloi ) and its variants usually refer to figures of Jesus' time. See the passages collected by De Lange 25 (155) n. 82.

68 There is no sign that Origen knew, or even heard of, the Mishnah. De Lange, Origen 34 suggests that the Mishnah is lurking behind the deuterôseis that are mentioned in (Rufinus' translation of) the prologue to the commentary on the Song of Songs (GCS Origenes Werke 8.62 = PG 13.63). This is unlikely; even if the word derives from Origen rather than Rufinus, in context it refers to traditions that are associated with Scripture, more like midrashim than mishnayot.

69 The editor of the Mishnah, R. Judah the Patriarch, is usually assigned a date of death around 220 CE (see e.g. Alexander Guttmann, "The Patriarch Judah I - His Birth and Death: A glimpse into the Chronology of the Talmudic Period," HUCA 25 [1954] 239-261); most scholars assume that our Mishnah received its finishing touches only in the generation after R. Judah the Patriarch. Hence the Mishnah in its current form can be dated to ca. 200-240 CE. Most modern discussions of the Mishnah avoid assigning a definitive date, perhaps because the question of date is inextricably connected with such questions as: How did the Mishnah come to be a book? Indeed, is the Mishnah a book at all in our sense? What does a date mean when assigned to a large anonymous anthological work such as the Mishnah?

70 There is no need to appeal to "Huillos the patriarch" to account for Origen's knowledge of these Mishnaic laws. On this mysterious figure, who is mentioned by Origen in Selecta in Psalmos (PG 12.1056) (the passage is also quoted by Jerome Contra Rufinum 1.13 CCSL 79.12-13, cited above in note 2), see De Lange, Origen 23-25. In one of his last works Origen refers to discussions with sophoi Ioudaiôn: (Contra Celsum 1.45, 1.55, 2.31), who may have been rabbinic sages; see Chadwick's note on CC 1.45, and see note 72 below. 
the teaching of a Hebraios (rendered Hebraeus magister or Hebraeus doctor by Rufinus) who explained that the two seraphim of Isaiah 6 represent the only-born of God (=Logos) and the holy spirit (ton monogenê tou theou kai to pneuma to hagion). Unless this Jew was a convert to Christianity, we may assume that he was an adherent of a Logos theology akin to that espoused by Philo two centuries earlier. ${ }^{71}$ It is most unlikely that he is the same Jew who informed Origen about rabbinic Sabbath law. ${ }^{72}$ The only thing we can say for sure about our informant is that he had connections with the rabbinic circles of the land of Israel. The presence of a rabbinic Jew in Alexandria in the early decades of the third century should occasion no surprise. During the catastrophic uprising of the Jews of Alexandria and Egypt against the Romans in 115-117 CE, the Jewish population of Alexandria was annihilated; it virtually disappears from the historical record. The Jewish population that resurfaces in Alexandria in the course of the third and fourth centuries seems to have consisted largely of émigrés from Roman Palaestina. ${ }^{73}$ We cannot be sure when this repopulation began but there is no reason to think that it could not have started in the early decades of the third century. Consequently while it is possible that Origen met this rabbinic informant during his sojourn in Caesarea in 215/6 CE, it is just as likely, I think, that Origen met him in Alexandria. Apparently the Jewish community in the city at that time, such as it was, included Jews of both the Philonic and the rabbinic type. In any case, there is no need to argue that this section of the De Principiis was added to the text after Origen moved to Caesarea in the 230s. ${ }^{74}$

This rabbinic Jew is an important witness to the formation of rabbinic tradition. He has informed Origen that the prohibition of nailed-sandals on the Sabbath is based on the prohibition of carrying burdens elaborated by Jeremiah 17:21. Mishnah Shabbat knows the same prohibition, and the Talmudim readily associate the prohibition of

${ }^{71}$ De Principiis 1.3 .4 pp. 52-53 ed. Koetschau; the same exegesis is reported at 4.3 .14 (26) p. 346. Philonic Jew or convert to Christianity? see Bardy, "Les traditions juives," 221, and Bietenhard, Caesarea 27.

72 In Contra Celsum 2.31 (pp. $92-93$ trans. Chadwick), Origen says "Although I have met with many Jews who were alleged to be wise, I have not heard any who approved of the opinion that the Son of God is the Logos."

${ }^{73}$ Allen Kerkeslager in Cambridge History of Judaism 4.66-67. Kerkeslager himself cites the silence of Origen as evidence that emigration from Palaestina had not yet begun in the early decades of the third century, but our passage provides evidence to the contrary. Several rabbinic texts assume the presence of rabbinic Jews in contemporary Alexandria: Y. Eruvin 3:9 21c (discussed by Lieberman in Ha Yerushalmi ki Feshuto p. 277-278); Y. Ketuvot 2:7 26d (parallels T. Peah 4:6 and T. Ketuvot 3:1); Zakkai of Alexandria is an amora of the fifth generation (mid fourth century). On the connections between the rabbis of Roman Palaestina and the Jews of the Roman diaspora, see now Yehuda Kurtzer, "'What Shall the Alexandrians Do?' Rabbinic Judaism and the Mediterranean Diaspora" (PhD dissertation, Harvard University, 2009).

${ }^{74}$ De Lange, Origen 9 (146) n. 34 tentatively suggests that our section was added to the De Principiis after Origen moved to Caesarea. This is not likely. Origen's preface to the De Principiis, which includes a kind of table of contents, clearly refers to the part of book 4 that is devoted to the interpretation of scripture and the reality of hidden or spiritual meanings of the law (1 praef. 8). Nowhere in his extensive introduction to the De Principiis does Paul Koetschau even mention the possibility that Origen later revised or expanded the work; thus on pp. cxxxvii-cxl, on the Inhalt und Gliederung der Schrift, there is no mention of the possibility that Origen revised it. 
carrying burdens with Jeremiah 17:22. What is amazing, however, is that both Talmudim ground the prohibition of nailed-sandals not in the laws of the Sabbath but in concern for public safety. Nailed sandals were thought to be responsible for some disaster in which many Jews were trampled to death. Hence the sages prohibited the wearing of nailed-sandals. This explanation cannot be right ${ }^{75}$; surely Mishnah Shabbat is talking about the laws of the Sabbath, not about issues of public policy. What pushed the Talmud to adopt this explanation, we do not know, but the Bavli attributes it to two sages of the mid third century, Samuel (an amora of the first generation) and Rami b. Yehezqel (an amora of the second generation). ${ }^{76}$ So, if we may accept the accuracy of the Bavli's attributions, two amoraim of the mid third century know this explanation, but in this paragraph of Origen we see this Mishnaic law before it became attached to its Talmudic interpretation. Nailed sandals are prohibited on the Sabbath because the nails constitute a burden; dramatic tales of panic and death have nothing to do with this law - yet.

Origen - or is it his informant? - has misprised the other Mishnaic law that is cited. The Mishnah says that carrying an object on "the shoulder" is prohibited on the Sabbath. The Mishnah of course means either one shoulder or two. Origen incorrectly states that carrying on one shoulder is prohibited, but not carrying on two shoulders. This mistake is important, because it shows that Origen derived his information from discussion with an informant, not observation of actual practice, and it shows that Origen's informant knew this rule in a form very close to that which would appear in Mishnah Shabbat. Perhaps the 2000 cubit Sabbath limit, which derives from "tradition," was part of the common Judaism as lived and practiced by broad reaches of the Jewish population, ${ }^{77}$ but the association of the 2000 cubit limit with Exodus 16:29 Origen could have learned only from discussion with a rabbinic Jew. Similarly, the prohibition of carrying on one shoulder Origen could have learned only from discussion with a rabbinic Jew. As to the prohibition of wearing nailed sandals on the Sabbath - I suppose that one could argue that this was part of the common Judaism of Origen's time, but I think it much simpler to assume that this prohibition too was the work of the rabbinic sages and was known to Origen only through his discussion with one of "the teachers of the Jews."

\footnotetext{
75 The stories may in themselves be historical, of course; I am questioning only their relevance to our Mishnah.

${ }^{76}$ The Bavli also attributes a version of this explanation to R. Ilai ben Eleazar, an amora mentioned here and nowhere else.

77 Ps. Ignatius, To the Magnesians 9 (ed. Lightfoot p. 173-174), "let each of you observe the Sabbath (sabbatizetô) spiritually ... not by eating stale meats, drinking lukewarm drinks, walking measured distances ... "I hope to discuss this text elsewhere.
} 